\title{
Ischemia-Modified Albumin Concentrations Should Be Interpreted with Caution in Patients with Low Serum Albumin Concentrations
}

\author{
David C. Gaze Lisa Crompton Paul Collinson \\ Department of Chemical Pathology, St. George's Healthcare NHS Trust, London, UK
}

\section{Key Words}

Cardiac ischaemia - Hypoalbuminaemia • Ischemia-modified albumin

\begin{abstract}
Objective: Ischemia-modified albumin (IMA $\left.{ }^{\circledR}\right)$ is a novel marker for assessing cardiac ischaemia. We assessed the relationship between total albumin concentrations and IMA in serum to investigate whether interpretation of IMA was albumin-dependent. Subjects and Methods: 298 serum samples were assayed for total albumin (albumin), using bromcresol purple, and IMA, using an indirect colorimetric assay. Correlations were investigated for the whole data set and for two subgroups, those samples with low albumin ( $\leq 34 \mathrm{~g} / \mathrm{l}$ ) and those with albumin within the reference interval. Results: There was a significant $(r=-0.888, p<0.0001)$ negative correlation between IMA and albumin both over the entire range of albumin concentrations and in the low albumin concentration subgroup $(r=-0.85, p<0.0001)$; however, there was less significant correlation in the subgroup with albumin within the reference interval $(r=-0.37, p<0.0001)$. Conclusion: A negative correlation exists between IMA and albumin concentrations; however, there is less significant correlation when albumin is within the reference interval. IMA concentrations determined in patients with albumin concentrations $\leq 34 \mathrm{~g} / \mathrm{l}$ should be interpreted with some caution.
\end{abstract}

\section{Introduction}

Ischemia-Modified Albumin (IMA ${ }^{\circledR}$ ) is a novel marker of cardiac ischaemia when measured by the AlbuminCobalt Binding $\left(\mathrm{ACB}^{\circledR}\right)$ test [1]. In conjunction with the electrocardiogram and serum troponin concentration, IMA can be used to detect cardiac ischaemia in patients with chest pain $[2,3]$ and is transiently elevated following percutaneous coronary intervention [4]. In non-ischaemic physiological conditions, plasma cobalt is bound to albumin, with minimal circulating free cobalt. However, during ischaemia, albumin is modified impeding the binding of cobalt to the N-terminus. Thus, IMA can be assessed by an indirect measurement that determines the cobalt binding capacity of albumin. We investigated the possible relationship between albumin and IMA concentrations.

\section{Methods}

298 serum samples were collected and assayed for albumin and for IMA within $2 \mathrm{~h}$ of albumin analysis, since IMA concentrations are known to be time-dependent [5]. Total albumin was determined using a bichromatic digital endpoint methodology using bromcresol purple reagent on a Synchron LX-20 and measured spectrophotometrically at $600 \mathrm{~nm}$ (Beckman Coulter, High Wycombe, UK) [6]. As documented by the manufacturer, the analytical detection limit was $10 \mathrm{~g} / \mathrm{l}$ with a reportable range up to $70 \mathrm{~g} / \mathrm{l}$. Total imprecision was $1.3-3.0 \%$ at $10-48 \mathrm{~g} / 1$.

IMA was assessed by an indirect measurement that determines the cobalt binding capacity of albumin exclusively in serum, using

\begin{tabular}{ll}
\hline KARGER & ( ) 2006 S. Karger AG, Basel \\
1011-7571/06/0154-0322\$23.50/0 \\
$\begin{array}{l}\text { Fax +4161306 } 1234 \\
\begin{array}{l}\text { E-Mail karger@karger.ch } \\
\text { www.karger.com }\end{array}\end{array}$ & $\begin{array}{l}\text { Accessible online at: } \\
\text { www.karger.com/mpp }\end{array}$
\end{tabular}

Dr. David C. Gaze

Department of Chemical Pathology, St. George's Healthcare NHS Trust Blackshaw Road, Tooting

London SW17 0QT (UK)

Tel. +44 208725 5878, Fax +44 208682 0744, E-Mail david.gaze@stgeorges.nhs.uk 
the ACB test (Ischemia Technologies, Denver, Colo., USA). The $\mathrm{ACB}$ test was performed on a Cobas MIRA Plus (ABX Diagnostics, UK). A known amount of cobalt in the form of cobalt chloride was added to a sample of serum and incubated for $8 \mathrm{~min}$. Dithiothreitol was added to react with the unbound cobalt forming a coloured complex that is measured spectrophotometrically at $500 \mathrm{~nm}$. The total assay imprecision, as reported by the manufacturer, was 4.9$7.5 \%$ at $73-140 \mathrm{kU} / 1$, respectively, and the analytical detection limit was reported as $14 \mathrm{kU} / 1$. The parametric 0.95 fractile upper reference limit of IMA has been determined previously to be $85 \mathrm{kU} / 1$ (interval: 46-90 kU/1).

A one-sample Kolmogorov-Smirnov test was performed to assess the normality of the distribution of the data. Pearson's correlation coefficients were calculated for all data, and for two subgroups, those with a low albumin $(\leq 34 \mathrm{~g} / \mathrm{l})$ and those within the conventional albumin reference interval (35-48 g/l). Statistical significance was held if $\mathrm{p}<0.05$. All analyses were performed using Analyse-it ${ }^{\circledR}$ (www.analyse-it.com) for Microsoft Excel ${ }^{\circledR}$.

\section{Results}

298 serum samples from 130 males of mean age 59 years (range 17-96 years) and 168 females of mean age 59 years (range 14-97 years) were collected by conventional venepuncture.

The mean albumin concentration was $31 \mathrm{~g} / 1$ (95\% CI 30-32 g/l). The mean IMA concentration was $107 \mathrm{kU} / \mathrm{l}$ (95\% CI 103-111 kU/1). The results for both quantities demonstrated normal distributions (KolmogorovSmirnov test: $p>0.15)$. A negative correlation was observed between albumin and IMA $(\mathrm{r}=-0.88 ; 95 \% \mathrm{CI}$ -0.91 to $-0.84, \mathrm{p}<0.0001)$ over the whole albumin concentration range (as shown in fig. 1a).

$193(65 \%)$ samples had albumin concentrations $\leq 34 \mathrm{~g} / \mathrm{l}$ and the relationship between IMA and albumin is shown in figure $1 \mathrm{~b}$. The mean albumin concentration for this subgroup was $25 \mathrm{~g} / \mathrm{l}(95 \% \mathrm{CI} 30-32 \mathrm{~g} / \mathrm{l})$. The mean IMA concentration was $107 \mathrm{kU} / 1$ (95\% CI 104-111 kU/l). A negative correlation between IMA and albumin was

Fig. 1. a Overall correlation between IMA and albumin concentrations ( $\mathrm{r}=-0.88 ; 95 \% \mathrm{CI}-0.91$ to $-0.84, \mathrm{p}<0.0001)$. b Correlation between IMA and albumin concentrations for the subgroup with low albumin concentrations $(\leq 34 \mathrm{~g} / \mathrm{l})(\mathrm{r}=-0.85 ; 95 \% \mathrm{CI}-0.89$ to $-0.79, \mathrm{p}<0.0001)$. c Correlation between IMA and albumin concentrations for the subgroup with albumin within the reference interval $(35-48 \mathrm{~g} / \mathrm{l})(\mathrm{r}=-0.3 ; 99 \% \mathrm{CI}-0.57$ to $-0.13, \mathrm{p}<0.0001)$.
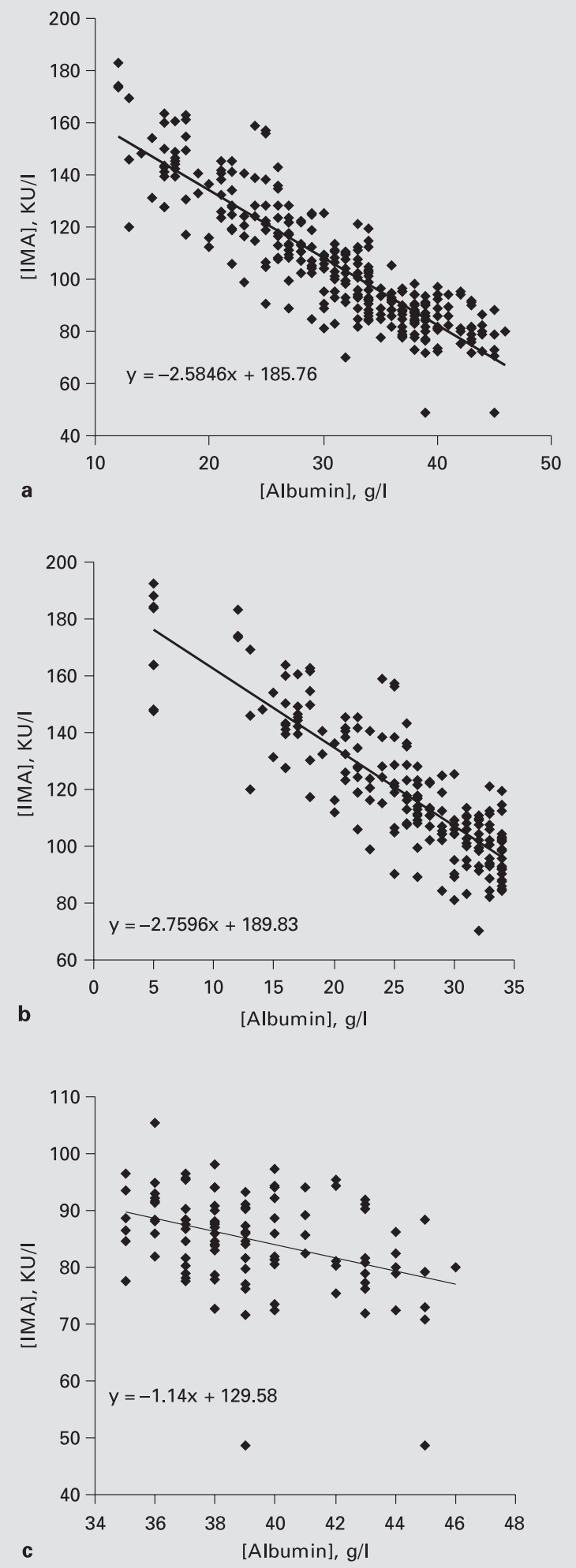
observed ( $\mathrm{r}=-0.85 ; 95 \% \mathrm{CI}-0.89$ to $-0.79, \mathrm{p}<0.0001)$. However, in the subgroup with albumin within the reference interval $(n=105)$ there was a less significant correlation between IMA and albumin $(\mathrm{r}=-0.37 ; 99 \% \mathrm{CI}-0.57$ to $-0.13, p<0.0001$ ) as shown in figure $1 \mathrm{c}$. The IMA concentrations in the low albumin group were significantly higher than those in the overall group.

\section{Discussion}

These data demonstrate a negative correlation between IMA and albumin concentrations in the albumin range of 10-49 $\mathrm{g} / 1$. This is in accordance with previously published data [7]. However, our data presented here show less of a negative correlation between IMA and albumin for samples with albumin within the reference interval.

\section{Conclusion}

The data show that IMA concentrations in patients who demonstrate hypoalbuminaemia ( $\leq 34 \mathrm{~g} / \mathrm{l})$ should be interpreted with caution. Whilst this is a clinical limitation of the use of the current assay, clinical studies are required in both patients with chest pain and non-chest pain who have low serum albumin to rule out other possible ischaemic pathologies that could cause this phenomenon.

\section{Acknowledgement}

The authors thank Ischemia Technologies Inc. for the provision of reagents.

This work was presented in part at the 56th Annual Meeting of the American Association for Clinical Chemistry, Los Angeles, Calif., USA, 25-29th July 2004.

\section{References}

-1 Bar-Or D, Lau E, Winkler JV: A novel assay for cobalt-albumin binding and its potential as a marker of myocardial ischemia: a preliminary report. J Emerg Med 2000;19:311-315.

-2 Bhagavan NV, Lai EM, Rios PA, Yang J, Ortega-Lopez AM, Shinoda H, et al: Evaluation of human serum albumin cobalt binding assay for the assessment of myocardial ischemia and myocardial infarction. Clin Chem 2003;49: 581-585.
-3 Sinha MK, Roy D, Gaze DC, Collinson PO, Kaski JC: Role of 'ischemia modified albumin', a new biochemical marker of myocardial ischaemia, in the early diagnosis of acute coronary syndromes. J Emerg Med 2004;21:29_ 34.

$\checkmark 4$ Sinha MK, Gaze DC, Tippins JR, Collinson PO, Kaski JC: Ischemia modified albumin is a sensitive marker of myocardial ischemia after percutaneous coronary intervention. Circulation 2003; 107:2403-2405.

5 Gaze DC, Crompton L, Collinson PO: Sample stability of ischaemia modified albumin (IMA) as assessed by the Albumin Cobalt Binding $\left(\mathrm{ACB}^{\mathrm{TM}}\right)$ test. Clin Chem 2003;49:A40.
-6 Pinnell AE, Northam BE: New automated dyebinding method for serum albumin determination with bromcresol purple. Clin Chem 1978; 24:80-86

7 Zapico-Muniz E, Santalo-Bel M, MerceMuntanola J, Montiel JA, Martinez-Rubio A Ordonez-Llanos J: Ischemia-modified albumin during skeletal muscle ischemia. Clin Chem 2004;50:1063-1065. 